\title{
The effect of the selected active substances of fungicides on the growth of Leptosphaeria maculans and Leptosphaeria biglobosa
}

\author{
Wpływ wybranych substancji czynnych fungicydów \\ na wzrost Leptosphaeria maculans i Leptosphaeria biglobosa
}

\author{
Joanna Kaczmarek ${ }^{1}$, Andrzej Brachaczek ${ }^{2}$, Małgorzata Jędryczka ${ }^{1}$ *
}

\begin{abstract}
Summary
The aim of this work was to compare the fungistatic activity of difenoconazole, tebuconazole and the mixture of tebuconazole and prothioconazole $(2: 1)$ on the growth of two fungal species: Leptosphaeria maculans and Leptosphaeria biglobosa. Both pathogens cause stem canker - a damaging disease of oilseed rape in Europe, Canada and Australia. The experiment was done in vitro using PDA (Potato Dextrose Agar) medium supplemented with 3 concentrations of the above listed compounds $(0.5 ; 1.0$ and $1.5 \mathrm{ppm})$. The results of two independent series of the biotest indicated that the examined fungicides inhibited the growth of $L$. maculans and L. biglobosa. The inhibition was dependent on the active substance and its concentration. The growth of mycelium of both Leptosphaeria species was inhibited the most by difenoconazole, even at the concentration of $0.5 \mathrm{ppm}$.
\end{abstract}

Key words: difenoconazole; tebuconazole; prothioconazole; Leptosphaeria spp.; stem canker

\author{
Streszczenie

\footnotetext{
${ }^{1}$ Instytut Genetyki Roślin Polskiej Akademii Nauk

Strzeszyńska 34, 60-479 Poznań

${ }^{2}$ Innvigo Sp. z o.o.

Al. Jerozolimskie 178, 02-486 Warszawa

*corresponding author: mjed@igr.poznan.pl
}

Celem pracy było zbadanie aktywności fungistatycznej difenokonazolu, tebukonazolu, jak i mieszaniny tebukonazolu z protiokonazolem (2:1) na wzrost grzybów: Leptosphaeria maculans i Leptosphaeria biglobosa. Oba patogeny powodują suchą zgniliznę kapustnych - groźną chorobę rzepaku w Europie, Kanadzie i Australii. Doświadczenia przeprowadzono w warunkach in vitro na pożywce PDA (Potato Dextrose Agar) z dodatkiem wymienionych wyżej substancji czynnych $(0,5 ; 1,0$ i 1,5 ppm) w porównaniu do kontroli. Wyniki z dwóch niezależnych serii biotestu wykazały, że badane fungicydy hamowały wzrost L. maculans i L. biglobosa. Inhibicja była zależna od stężenia i rodzaju substancji czynnej. Difenokonazol wykazywał najlepszą skuteczność w ograniczaniu wzrostu grzybni obu gatunków Leptosphaeria, nawet przy stężeniu 0,5 ppm.

Słowa kluczowe: difenokonazol; tebukonazol; protiokonazol; Leptosphaeria spp.; sucha zgnilizna kapustnych 


\section{Wstęp / Introduction}

Dwa blisko spokrewnione gatunki Leptosphaeria maculans oraz Leptosphaeria biglobosa powodują suchą zgniliznę kapustnych - jedną z najgroźniejszych chorób rzepaku (Mendes-Pereira i wsp. 2003; Fitt i wsp. 2006). Cykl życiowy grzybów L. maculans i L. biglobosa ma bardzo podobny przebieg. W Australii, Kanadzie i Europie pierwotnym źródłem porażenia roślin rzepaku są zarodniki workowe - askospory, które powstają w pseudotecjach owocnikach stadium doskonałego, znajdujących się na resztkach pożniwnych pochodzących z poprzedniego sezonu wegetacyjnego (Jędryczka 2006). Zgodnie z danymi literaturowymi, gatunek L. maculans poraża podstawę łodygi, co powoduje przerwanie wiązek przewodzących i zamieranie całej rośliny często już w stadium kwitnienia, natomiast gatunek L. biglobosa wywołuje rozległe, lecz powierzchniowe plamy na łodydze (West i wsp. 2001). Jednakże identyfikacja grzybów zasiedlających podstawę łodyg rzepaku z objawami suchej zgnilizny kapustnych w Polsce wykazuje częstą obecność L. biglobosa, co świadczy, że gatunek ten może być znacznie groźniejszy niż dotychczas uznawano (Jędryczka 2006).

Izolaty L. maculans są wysoko wyspecjalizowanymi patogenami o poznanej interakcji gen na gen (Balesdent i wsp. 2002). Takie interakcje nie zostały zaobserwowane u gatunku L. biglobosa. Jest on jednak także zdolny do wywoływania objawów choroby u wielu roślin kapustowatych (Gall i wsp. 1995). Ten gatunek grzyba wyodrębniono z gatunku L. maculans dopiero w 2001 roku, na podstawie różnic morfologicznych dotyczących budowy pseudotecjów (Shoemaker i Brun 2001). Zazwyczaj do wyróżnienia gatunku wymagana jest odmienność morfologiczna, lecz budowa owocników nie jest jedyną cechą różnicującą omawiane patogeny. Oba gatunki różnią się licznymi, innymi cechami morfologicznymi, a także chorobotwórczością wobec rzepaku (West i wsp. 2001).

Badania różnych autorów wskazują na odmienne oddziaływanie fungicydów na wzrost L. biglobosa i L. maculans. W doświadczeniach przeprowadzonych przez Eckert i wsp. (2004) izolaty obu gatunków były bardziej wrażliwe na flusilazol, niż na tebukonazol. W literaturze naukowej nie ma zgodności co do oznaczenia wrażliwości gatunków Leptosphaeria na działanie substancji czynnych (s.cz.). Niektórzy autorzy (Eckert i wsp. 2009; Kaczmarek i Jędryczka 2010) uważają, że gatunek L. maculans jest bardziej na nie wrażliwy, gdy tymczasem w badaniach prowadzonych przez Gwiazdowskiego (2008) nie stwierdzono statystycznie istotnych różnic $\mathrm{w}$ działaniu substancji grzybobójczych na wzrost grzybów L. maculans i L. biglobosa.

Odmienne wyniki dotyczące wrażliwości obu patogenów zachęcają do określenia skuteczności kolejnych s.cz., tym bardziej, że przytoczone badania wykonano przy zastosowaniu s.cz., które już wycofano z rynku. Z powszechności występowania L. biglobosa na rzepaku w Polsce (Kaczmarek i wsp. 2014) można wnioskować o niewielkiej wrażliwości tego gatunku na dostępne środki grzybobójcze. Można też przypuszczać, że wieloletnie traktowanie roślin porażonych przez L. biglobosa zbyt niskimi dawkami, niedostatecznymi do zwalczenia tego grzyba, spowodowało że gatunek ten jest niewrażliwy na działanie wielu substancji chemicznych.

Celem badań było porównanie skuteczności trzech związków z grupy chemicznej triazoli w ograniczaniu wzrostu grzybów L. maculans i L. biglobosa. Miernikiem oddziaływania s.cz. na dany gatunek był ich wpływ na wzrost grzybni w warunkach in vitro.

\section{Materiały i metody / Materials and methods}

W testach służących oznaczeniu wrażliwości na s.cz. wybranych fungicydów zastosowano po 3 izolaty grzybów L. maculans i L. biglobosa (tab. 1). Doświadczenia przeprowadzono $\mathrm{w}$ komorach fitotronowych $\mathrm{w}$ temperaturze $16^{\circ} \mathrm{C}$, bez dostępu światła (MYTRON Bio-und Solartechnik GmbH, Heiligenstadt, Niemcy). Wzrost izolatów badano na pożywce PDA (Potato Dextrose Agar) umieszczonej w płytkach Petriego o średnicy $90 \mathrm{~mm}$. Do sterylnej pożywki o temperaturze około $45^{\circ} \mathrm{C}$ dodawano roztwory wodne preparatów fungicydowych w ilości pozwalającej uzyskać stężenie s.cz. równe: 0,$5 ; 1,0 ; 1,5$ ppm. Kombinację kontrolną stanowiła pożywka bez dodatku fungicydu. W doświadczeniu zastosowano preparat Dafne 250 EC (difenokonazol $250 \mathrm{~g} / \mathrm{l}$ ), Horizon 250 EW (tebukonazol $250 \mathrm{~g} / \mathrm{l}$ ) oraz Tilmor 240 EC (protiokonazol $80 \mathrm{~g} / 1$ + tebukonazol $160 \mathrm{~g} / \mathrm{l})$.

Fragmenty liści i łodyg z objawami suchej zgnilizny kapustnych odkażano, a następnie wykładano na pożywkę PDA z dodatkiem 0,02\% siarczanu streptomycyny. Z wyrastającej kolonii grzyba pod binokularem Stemi DR 1040 (Zeiss) pobierano końcowy fragment pojedynczej strzępki i przenoszono na nową pożywkę PDA. Zabieg ten powtarzano do uzyskania kultury wolnej od bakterii i innych patogenów, co sprawdzano hodując je na płynnej pożywce Czapka-Doxa $\mathrm{z}$ dodatkiem ekstraktu drożdżowego (2 g/l). Izolaty przechowywano na fragmentach pożywki $(0,5 \times$ $1,5 \mathrm{~cm}) \mathrm{w}$ sterylnych probówkach, uszczelnionych taśmą Parafilm, w temperaturze $4^{\circ} \mathrm{C}$. Izolaty odnawiano co 6 miesięcy. Rok pobrania próby i jej pochodzenie nie miały wpływu na tempo wzrostu. Przed rozpoczęciem doświadczenia badane izolaty wykładano na pożywkę PDA i hodowano przez 21 dni (tab. 1). Ze środka kolonii wycinano krążki za pomocą korkoboru niklowanego o średnicy $5 \mathrm{~mm}$ (Bochem Instrumente GmbH, 12430). Krążek przerośnięty grzybnią danego izolatu umieszczano $\mathrm{w}$ środku płytki $\mathrm{z}$ dodatkiem s.cz. fungicydu. Wszystkie powyższe prace wykonano $\mathrm{w}$ warunkach sterylnych w komorze laminarnej (POLON KL-21).

W celu oznaczenia szybkości wzrostu, co trzy dni mierzono średnice kolonii. Dla uzyskania identycznych warunków temperaturowych doświadczenia z zastosowaniem izolatów L. maculans i L. biglobosa wykonywano w tej samej komorze klimatycznej. Ze względu na regularny (okrągły lub lekko eliptyczny) kształt kolonii L. biglobosa pomiary średnicy kolonii izolatów tego gatunku wykonywano wzdłuż dwóch linii - najszerszej i prostopadłej do niej. Kształt kolonii L. maculans był nieregularny, w związku z tym mierzono największą i najmniejszą średnicę kolonii. Pomiary prowadzono do momentu poprzedzającego osiągnięcie przez kulturę kontrolną 
grzyba L. biglobosa średnicy szalki Petriego. Dla każdego wariantu (izolat $\times$ pożywka $z$ odpowiednim stężeniem fungicydu) zastosowano trzy powtórzenia. Doświadczenie wykonano w dwóch seriach, a uzyskane wyniki uśredniono.

Aktywność fungistatyczną testowanych s.cz. oceniano na podstawie procentu zahamowania wzrostu kolonii grzybów (Borecki 1984). Wnioskowanie dotyczące istotności różnic między obiektami badawczymi prowadzono na podstawie analizy wariancji. W przypadku, gdy analiza wariancji nie wykazała istotności różnic między rozpatrywanymi grupami, nie przeprowadzano już dalszych testów. Natomiast, gdy hipoteza zerowa została odrzucona w analizie wariancji, badanie różnic między średnimi z poszczególnych grup przeprowadzono testem Tukeya. Wszystkie wykazane różnice przyjęto za statystycznie istotne przy poziomie istotności $\alpha=0,05$. Analizy przeprowadzono za pomocą programu statystycznego GenStat Release 12.1 (Payne i wsp. 2007).

\section{Wyniki i dyskusja / Results and discussion}

Wzrost grzybni L. biglobosa był od 1,46 do 2,34 razy szybszy niż L. maculans (tab. 2, 3). Podobną zależność stwierdzili Karolewski (1998) i Jędryczka (2006). W ich badaniach różnica między wzrostem izolatów L. maculans i L. biglobosa była około 2,5-krotna na korzyść L. biglobosa.

W przypadku grzyba L. maculans brak różnic między szybkością wzrostu izolatów kontrolnych a szczepami rosnącymi na pożywce $\mathrm{z}$ dodatkiem fungicydu odnotowano jedynie $\mathrm{w}$ dziewiątym dniu hodowli dla grzybów rosnących na pożywce $\mathrm{z}$ preparatem Tilmor 240 EC w stężeniu s.cz. wynoszącym 0,5 ppm. Z kolei w przypadku L. biglobosa taki brak różnic stwierdzono dla izolatów hodowanych na pożywce $\mathrm{z}$ dodatkiem preparatu Tilmor 240 EC w stężeniu 0,5 ppm s.cz. w 3 i 18 dniu wzrostu oraz na podłożu z preparatem Horizon $250 \mathrm{EW}$ w stężeniu s.cz. 0,5 ppm w 18 dniu hodowli (tab. 2, 3). W każdym pozostałym przypadku różnice między wzrostem kontroli a izolatów tych grzybów na pożywce z s.cz. fungicydów były istotne statystycznie. Tą samą zależność wykazał
Karolewski (1998) oraz w większości przypadków także Gwiazdowski (2008).

W prezentowanej pracy, w badanym zakresie stężeń wahającym się od 0,5 do 1,5 ppm najsłabsze działanie fungistatyczne miały najniższe dawki preparatów, a ich efektywność wzrastała wraz ze zwiększaniem dawki. Taką samą tendencję zaobserwowali Karolewski (1998) oraz Gwiazdowski (2008).

Aktywność fungistatyczna testowanych s.cz. wyrażona jako współczynnik zahamowania tempa wzrostu patogena wahała się od 47,7 do $98,6 \%$ dla grzyba L. maculans i od 41,9 do 99,1\% dla L. biglobosa (tab. 4). Wśród badanych substancji - difenokonazol najskuteczniej hamował wzrost obu patogenów w każdym badanym stężeniu (średnio o 97\%). Tebukonazol dodawany do pożywki w stężeniu 1,5 ppm hamował wzrost grzybni L. maculans $(78 \%)$ oraz L. biglobosa (64\%). Podobne wyniki uzyskał Gwiazdowski (2008), w którego badaniach fungicyd Horizon $250 \mathrm{EW}$ zawierający tebukonazol znacznie ograniczał rozwój kultur już przy stężeniu 1 ppm s.cz., natomiast w stężeniu 10 ppm i wyższym uniemożliwiał ich wzrost. W badaniach prowadzonych w niniejszej pracy tebukonazol znajdujący się w preparacie Horizon 250 EW charakteryzował się również większą aktywnością fungistatyczną niż mieszanina protiokonazolu i tebukonazolu $\mathrm{w}$ stosunku 2:1 w preparacie Tilmor $240 \mathrm{EC}$, gdy był dodany do pożywki w stężeniu 1 i 0,5 ppm. Najprawdopodobniej protiokonazol obecny w tej mieszaninie ma mniejszy wpływ na jej właściwości grzybobójcze względem sprawców suchej zgnilizny kapustnych, co zostało zauważone także przez Sewell i wsp. (2014) w warunkach polowych.

Jak dotąd, wobec sprawców suchej zgnilizny kapustnych nie prowadzono $\mathrm{w}$ warunkach in vitro testów aktywności fungistatycznej preparatów zawierających wyłącznie difenokonazol. W warunkach polowych testowano preparat Toprex 375 SC (difenokonazol $250 \mathrm{~g} / 1+$ paklobutrazol $125 \mathrm{~g} / \mathrm{l}$ ), który cechował się wysoką skutecznością w zwalczaniu patogenów powodujących suchą zgniliznę kapustnych (Jędryczka i Kaczmarek 2011). W Wielkiej Brytanii Gladders i wsp. (1998) potwierdzili w doświadczeniach polowych skuteczność difenokonazolu w ograniczaniu suchej zgnilizny kapustnych, ale badania te prowadzono wyłącznie dla gatunku L. maculans. We

Tabela 1. Charakterystyka izolatów Leptosphaeria maculans i Leptosphaeria biglobosa zastosowanych w badaniach Table 1. Isolates of Leptosphaeria maculans and Leptosphaeria biglobosa used in the study

\begin{tabular}{|c|c|c|c|c|c|c|}
\hline $\begin{array}{l}\text { Lp. } \\
\text { No. }\end{array}$ & $\begin{array}{l}\text { Gatunek } \\
\text { Species }\end{array}$ & $\begin{array}{l}\text { Kod izolatu } \\
\text { Isolate code }\end{array}$ & $\begin{array}{c}\text { Rok izolacji } \\
\text { Year of isolation }\end{array}$ & $\begin{array}{l}\text { Organ rzepaku } \\
\text { Plant part }\end{array}$ & $\begin{array}{l}\text { Pochodzenie } \\
\text { Origin }\end{array}$ & $\begin{array}{c}\text { Kraj } \\
\text { Country }\end{array}$ \\
\hline 1 & \multirow{3}{*}{ Leptosphaeria maculans } & $1-1$ & 2002 & łodyga - stem & Teendorf & Niemcy-Germany \\
\hline 2 & & $1-2$ & 2005 & \multirow[t]{2}{*}{ liść - leaf } & Opava & $\begin{array}{l}\text { Republika Czeska } \\
\text { Czech Republic }\end{array}$ \\
\hline 3 & & $1-3$ & 2011 & & Cerekwica & Polska-Poland \\
\hline 4 & \multirow{3}{*}{ Leptosphaeria biglobosa } & $2-1$ & 2002 & łodyga - stem & Boxworth & $\begin{array}{l}\text { Wielka Brytania } \\
\text { Great Britain }\end{array}$ \\
\hline 5 & & $2-2$ & 2007 & \multirow[b]{2}{*}{ liść - leaf } & Głubczyce & Polska-Poland \\
\hline 6 & & $2-3$ & 2013 & & Šumperk & $\begin{array}{l}\text { Republika Czeska } \\
\text { Czech Republic }\end{array}$ \\
\hline
\end{tabular}


Tabela 2. Średni przyrost grzybni izolatów Leptosphaeria maculans na pożywce PDA (Potato Dextrose Agar) z dodatkiem substancji czynnych fungicydów

Table 2. The average growth of Leptosphaeria maculans isolates on PDA (Potato Dextrose Agar) medium supplemented with active substances of fungicides

\begin{tabular}{|c|c|c|c|c|c|c|c|}
\hline \multirow{2}{*}{$\begin{array}{c}\text { Stężenie } \\
\text { Concentration } \\
\text { [ppm] }\end{array}$} & \multirow[t]{2}{*}{$\begin{array}{c}\text { Fungicyd }- \text { Fungicide } \\
\text { (substancja czynna - active substance) }\end{array}$} & \multicolumn{6}{|c|}{$\begin{array}{l}\text { Średnica kolonii grzyba } \\
\text { Diameter of fungal colony } \\
{[\mathrm{mm}]}\end{array}$} \\
\hline & & $3 \mathrm{dpi}^{1}$ & 6 dpi & 9 dpi & 12 dpi & $15 \mathrm{dpi}$ & 18 dpi \\
\hline 0 & kontrola - control & 9,6 & 10,0 & 17,9 & 26,2 & 39,5 & 44,1 \\
\hline \multirow{3}{*}{0,5} & Dafne 250 EC (difenokonazol - difenoconazole $250 \mathrm{~g} / \mathrm{l})$ & $0,4 \mathrm{a}^{2}$ & $0,8 \mathrm{a}$ & $1,7 \mathrm{a}$ & $0,7 \mathrm{a}$ & $1,4 \mathrm{a}$ & $2,3 \mathrm{a}$ \\
\hline & Horizon 250 EW (tebukonazol - tebuconazole $250 \mathrm{~g} / \mathrm{l}$ ) & $1,8 \mathrm{~b}$ & $4,1 \mathrm{~b}$ & $9,7 \mathrm{~b}$ & $14,1 \mathrm{~b}$ & $19,1 \mathrm{~b}$ & $21,3 \mathrm{~b}$ \\
\hline & $\begin{array}{l}\text { Tilmor } 240 \text { EC (protiokonazol - prothioconazole } 80 \mathrm{~g} / 1+ \\
\text { tebukonazol - tebuconazole } 160 \mathrm{~g} / \mathrm{l} \text { ) }\end{array}$ & $2,3 \mathrm{~b}$ & $5,9 \mathrm{~b}$ & $12,4 b^{3 *}$ & $16,0 \mathrm{~b}$ & $21,8 \mathrm{~b}$ & $23,4 \mathrm{~b}$ \\
\hline \multirow{3}{*}{1} & Dafne 250 EC (difenokonazol - difenoconazole $250 \mathrm{~g} / \mathrm{l}$ ) & $0,2 \mathrm{a}$ & $0,7 \mathrm{a}$ & $0,8 \mathrm{a}$ & $1,1 \mathrm{a}$ & $1,4 \mathrm{a}$ & $1,5 \mathrm{a}$ \\
\hline & Horizon 250 EW (tebukonazol - tebuconazole $250 \mathrm{~g} / \mathrm{l}$ ) & $1,7 \mathrm{~b}$ & $1,9 \mathrm{a}$ & $5,7 \mathrm{~b}$ & $8,4 \mathrm{~b}$ & $11,0 \mathrm{~b}$ & $11,5 \mathrm{~b}$ \\
\hline & $\begin{array}{l}\text { Tilmor } 240 \text { EC (protiokonazol - prothioconazole } 80 \mathrm{~g} / 1+ \\
\text { tebukonazol - tebuconazole } 160 \mathrm{~g} / 1 \text { ) }\end{array}$ & $2,1 \mathrm{~b}$ & $5,7 \mathrm{~b}$ & $10,7 \mathrm{c}$ & $15,0 \mathrm{c}$ & $19,2 \mathrm{c}$ & $19,9 \mathrm{c}$ \\
\hline \multirow{3}{*}{1,5} & Dafne 250 EC (difenokonazol - difenoconazole $250 \mathrm{~g} / \mathrm{l}$ ) & $0,0 \mathrm{a}$ & $0,0 \mathrm{a}$ & $0,3 \mathrm{a}$ & $0,4 \mathrm{a}$ & $0,5 \mathrm{a}$ & $0,8 \mathrm{a}$ \\
\hline & Horizon 250 EW (tebukonazol - tebuconazole $250 \mathrm{~g} / \mathrm{l}$ ) & $1,7 \mathrm{~b}$ & $1,8 \mathrm{a}$ & $3,7 \mathrm{a}$ & $7,2 \mathrm{~b}$ & $9,7 \mathrm{~b}$ & $10,2 \mathrm{~b}$ \\
\hline & $\begin{array}{l}\text { Tilmor } 240 \mathrm{EC} \text { (protiokonazol - prothioconazole } 80 \mathrm{~g} / \mathrm{l}+ \\
\text { tebukonazol - tebuconazole } 160 \mathrm{~g} / \mathrm{l} \text { ) }\end{array}$ & $1,9 \mathrm{~b}$ & $4,0 \mathrm{~b}$ & $8,9 \mathrm{~b}$ & $11,6 \mathrm{~b}$ & $11,9 \mathrm{~b}$ & $15,9 \mathrm{~b}$ \\
\hline
\end{tabular}

${ }^{1} \mathrm{dpi}$ - liczba dni po inokulacji - number of days post inoculation

2 średnie w kolumnach dla danego stężenia oznaczone tą samą literą nie różnią się między sobą na poziomie istotności $\alpha=0,05$ - means in columns for each concentration followed by shared letters denote no statistical differences at $\alpha=0.05$

${ }^{3}$ średnie wartości w kolumnach oznaczone gwiazdką (*) nie różnią się istotnie na poziomie $\alpha=0,05$ od kontroli - means in columns marked with asterix (*) do not differ significantly from control at $\alpha=0.05$

Tabela 3. Średni przyrost grzybni izolatów Leptosphaeria biglobosa na pożywce PDA (Potato Dextrose Agar) z dodatkiem substancji czynnych fungicydów

Table 3. The average growth of Leptosphaeria biglobosa isolates on PDA (Potato Dextrose Agar) medium supplemented with active substances of fungicides

\begin{tabular}{|c|c|c|c|c|c|c|c|}
\hline \multirow{2}{*}{$\begin{array}{l}\text { Stężenie } \\
\text { Concen- } \\
\text { tration } \\
{[\mathrm{ppm}]}\end{array}$} & \multirow{2}{*}{$\begin{array}{c}\text { Fungicyd }- \text { Fungicide } \\
\text { (substancja czynna - active substance) }\end{array}$} & \multicolumn{6}{|c|}{$\begin{array}{c}\text { Średnica kolonii grzyba } \\
\text { Diameter of colony } \\
{[\mathrm{mm}]}\end{array}$} \\
\hline & & $3 \mathrm{dpi}^{1}$ & 6 dpi & 9 dpi & 12 dpi & 15 dpi & $18 \mathrm{dpi}$ \\
\hline 0 & kontrola - control & 14,1 & 21,0 & 44,2 & 59,6 & 75,7 & 78,0 \\
\hline \multirow{3}{*}{0,5} & Dafne 250 EC (difenokonazol - difenoconazole $250 \mathrm{~g} / \mathrm{l}$ ) & $7,0 \mathrm{a}^{2}$ & $7,3 \mathrm{a}$ & $7,9 \mathrm{a}$ & $8,2 \mathrm{a}$ & $9,2 \mathrm{a}$ & $10,7 \mathrm{a}$ \\
\hline & Horizon $250 \mathrm{EW}$ (tebukonazol - tebuconazole $250 \mathrm{~g} / \mathrm{l}$ ) & $11,0 \mathrm{~b}$ & $11,1 \mathrm{~b}$ & $31,7 \mathrm{~b}$ & $42,7 \mathrm{~b}$ & $52,9 \mathrm{~b}$ & $61,1 b^{*}$ \\
\hline & $\begin{array}{l}\text { Tilmor } 240 \text { EC (protiokonazol - prothioconazole } 80 \mathrm{~g} / 1+ \\
\text { tebukonazol - tebuconazole } 160 \mathrm{~g} / \mathrm{l} \text { ) }\end{array}$ & $12,8 \mathrm{c}^{3 *}$ & $12,9 \mathrm{~b}$ & $34,0 \mathrm{~b}$ & $43,7 \mathrm{~b}$ & $54,4 \mathrm{~b}$ & $61,7 b^{*}$ \\
\hline \multirow{3}{*}{1} & Dafne 250 EC (difenokonazol - difenoconazole $250 \mathrm{~g} / \mathrm{l}$ ) & $7,0 \mathrm{a}$ & $7,1 \mathrm{a}$ & $7,2 \mathrm{a}$ & $7,5 \mathrm{a}$ & $8,1 \mathrm{a}$ & $9,0 \mathrm{a}$ \\
\hline & Horizon 250 EW (tebukonazol - tebuconazole $250 \mathrm{~g} / \mathrm{l}$ ) & $9,7 \mathrm{~b}$ & $13,2 \mathrm{a}$ & $25,2 \mathrm{~b}$ & $32,0 \mathrm{~b}$ & $40,3 \mathrm{~b}$ & $46,8 \mathrm{~b}$ \\
\hline & $\begin{array}{l}\text { Tilmor } 240 \text { EC (protiokonazol - prothioconazole } 80 \mathrm{~g} / 1+ \\
\text { tebukonazol - tebuconazole } 160 \mathrm{~g} / \mathrm{l} \text { ) }\end{array}$ & $11,2 \mathrm{c}$ & $17,2 \mathrm{~b}$ & $29,7 \mathrm{c}$ & $38,2 \mathrm{c}$ & $47,5 \mathrm{c}$ & $52,2 \mathrm{~b}$ \\
\hline \multirow{3}{*}{1,5} & Dafne 250 EC (difenokonazol - difenoconazole $250 \mathrm{~g} / \mathrm{l}$ ) & $7,0 \mathrm{a}$ & $7,0 \mathrm{a}$ & $7,0 \mathrm{a}$ & $7,0 \mathrm{a}$ & $7,4 \mathrm{a}$ & $7,6 \mathrm{a}$ \\
\hline & Horizon 250 EW (tebukonazol - tebuconazole $250 \mathrm{~g} / \mathrm{l}$ ) & $8,9 \mathrm{~b}$ & $11,0 \mathrm{a}$ & $22,9 \mathrm{~b}$ & $28,7 \mathrm{~b}$ & $37,2 \mathrm{~b}$ & $43,4 \mathrm{~b}$ \\
\hline & $\begin{array}{l}\text { Tilmor } 240 \text { EC (protiokonazol - prothioconazole } 80 \mathrm{~g} / 1+ \\
\text { tebukonazol - tebuconazole } 160 \mathrm{~g} / \mathrm{l} \text { ) }\end{array}$ & $10,2 \mathrm{~b}$ & $15,2 \mathrm{~b}$ & $25,6 \mathrm{~b}$ & $32,9 \mathrm{~b}$ & $42,3 \mathrm{~b}$ & $48,7 \mathrm{c}$ \\
\hline
\end{tabular}

\footnotetext{
${ }^{1} \mathrm{dpi}$ - liczba dni po inokulacji - number of days post inoculation

2 średnie w kolumnach dla danego stężenia oznaczone tą samą literą nie różnią się między sobą na poziomie istotności $\alpha=0,05$ - means in columns for each concentration followed by shared letters denote no statistical differences at $\alpha=0.05$

${ }^{3}$ średnie wartości w kolumnach oznaczone gwiazdką (*) nie różnią się istotnie na poziomie $\alpha=0,05$ od kontroli - means in columns marked with asterix (*) do not differ significantly from control at $\alpha=0.05$
} 
Tabela 4. Aktywność fungistatyczna testowanych substancji czynnych

Table 4. Fungistatic activity of tested active substances

\begin{tabular}{|c|c|c|c|}
\hline \multirow{2}{*}{$\begin{array}{c}\text { Stężenie } \\
\text { Concentration } \\
\text { [ppm] }\end{array}$} & \multirow[t]{2}{*}{$\begin{array}{c}\text { Fungicyd }- \text { Fungicide } \\
\text { (substancja czynna - active substance) }\end{array}$} & \multicolumn{2}{|c|}{$\begin{array}{c}\text { Zahamowanie wzrostu patogena } \\
\text { Inhibition of pathogen's growth } \\
{[\%]}\end{array}$} \\
\hline & & Leptosphaeria maculans & Leptosphaeria biglobosa \\
\hline \multirow{3}{*}{0,5} & Dafne 250 EC (difenokonazol - difenoconazole $250 \mathrm{~g} / \mathrm{l})$ & $94,3 \mathrm{e}$ & $94,8 \mathrm{c}$ \\
\hline & Horizon 250 EW (tebukonazol - tebuconazole $250 \mathrm{~g} / \mathrm{l}$ ) & $47,4 \mathrm{a}$ & 41,9 a \\
\hline & $\begin{array}{l}\text { Tilmor } 240 \text { EC (protiokonazol - prothioconazole } 80 \mathrm{~g} / 1+ \\
\text { tebukonazol - tebuconazole } 160 \mathrm{~g} / 1 \text { ) }\end{array}$ & $50,3 \mathrm{a}$ & 44,7 a \\
\hline \multirow{3}{*}{1} & Dafne 250 EC (difenokonazol - difenoconazole $250 \mathrm{~g} / \mathrm{l})$ & $95,7 \mathrm{e}$ & $99,4 \mathrm{c}$ \\
\hline & Horizon 250 EW (tebukonazol - tebuconazole $250 \mathrm{~g} / \mathrm{l}$ ) & $65,9 \mathrm{c}$ & $59,7 \mathrm{~b}$ \\
\hline & $\begin{array}{l}\text { Tilmor } 240 \text { EC (protiokonazol - prothioconazole } 80 \mathrm{~g} / 1+ \\
\text { tebukonazol - tebuconazole } 160 \mathrm{~g} / \mathrm{l} \text { ) }\end{array}$ & $57,9 \mathrm{~b}$ & $51,9 \mathrm{ab}$ \\
\hline \multirow{3}{*}{1,5} & Dafne 250 EC (difenokonazol - difenoconazole $250 \mathrm{~g} / \mathrm{l}$ ) & $98,5 \mathrm{e}$ & $99,1 \mathrm{c}$ \\
\hline & Horizon 250 EW (tebukonazol - tebuconazole $250 \mathrm{~g} / \mathrm{l}$ ) & $78,0 \mathrm{~d}$ & $64,0 \mathrm{~b}$ \\
\hline & $\begin{array}{l}\text { Tilmor } 240 \text { EC (protiokonazol - prothioconazole } 80 \mathrm{~g} / 1+ \\
\text { tebukonazol - tebuconazole } 160 \mathrm{~g} / 1 \text { ) }\end{array}$ & $53,4 \mathrm{ab}$ & $57,7 \mathrm{ab}$ \\
\hline
\end{tabular}

Średnie w kolumnach oznaczone tą samą literą nie różnią się między sobą na poziomie istotności $\alpha=0,05$

Means in columns followed by shared letters denote no statistical differences at $\alpha=0.05$

wcześniejszych badaniach stwierdzono, że do zahamowania wzrostu izolatów L. biglobosa $\mathrm{w}$ warunkach in vitro wymagane są 2-3-krotnie wyższe dawki flusilazolu niż dla L. maculans (Kaczmarek i Jędryczka 2010). Natomiast w badaniach prowadzonych $\mathrm{w}$ niniejszej pracy difenokonazol równie skutecznie hamował wzrost $L$. maculans, jak i L. biglobosa, nawet w najniższych stężeniach (tab. 2, 3). Jest to informacja istotna dla praktyki rolniczej, ponieważ w związku ze wzrostem powierzchni uprawy odmian rzepaku z genem $R \operatorname{lm} 7$ warunkującym odporność na L. maculans, można się spodziewać powszechniejszego występowania gatunku L. biglobosa w Polsce.

W przypadku upraw monokulturowych rzepaku, z którymi mamy do czynienia we wszystkich krajach, w których jest uprawiany, dochodzi do nagromadzenia patogenów, szkodników oraz do kompensacji chwastów. Ważnym sposobem utrzymania wysokiej zdrowotności roślin jest umiejętne stosowanie środków ochrony roślin.
W przypadku grzybów powodujących suchą zgniliznę kapustnych istotnym elementem tego działania jest zastosowanie skutecznych fungicydów i ich aplikacja w odpowiednim terminie (Kaczmarek i wsp. 2014).

\section{Wnioski / Conclusions}

1. Tempo wzrostu grzybni L. biglobosa było większe niż L. maculans.

2. W warunkach in vitro preparaty Dafne 250 EC, Horizon 250 EW oraz Tilmor 240 EC w każdym testowanym stężeniu ograniczały wzrost grzybni obu patogenów powodujących suchą zgniliznę kapustnych.

3. Aktywność fungistatyczna preparatu Dafne 250 EC była istotnie wyższa aniżeli Horizon $250 \mathrm{EW}$ oraz Tilmor 240 EC i uzależniona od stężenia s.cz. oraz gatunku Leptosphaeria.

\section{Literatura / References}

Balesdent M.H., Attard A., Kuhn M.-L., Rouxel T. 2002. New avirulence genes in the phytopathogenic fungus Leptosphaeria maculans. Phytopathology 92 (10): 1122-1133.

Borecki Z. 1984. Fungicydy stosowane w ochronie roślin. PWN, Warszawa, 173 ss.

Eckert M.R., Fitt B.D.L., Selley A. 2004. Leptosphaeria maculans, L. biglobosa and fungicides: preliminary results from in vitro and winter oilseed rape experiments. International Organisation for Biological Control Bulletin 27 (10): 157-164.

Eckert M., Rossall S., Selley A., Fitt B.D.L. 2009. Effects of fungicides on in vitro spore germination and mycelial growth of the phytopathogens Leptosphaeria maculans and L. biglobosa (phoma stem canker of oilseed rape). Pest Management Science 66 (4): 396-405.

Fitt B.D.L., Brun H., Barbetti M.J., Rimmer S.R. 2006. World-wide importance of phoma stem canker (Leptosphaeria maculans and L. biglobosa) on oilseed rape (Brassica napus). European Journal of Plant Pathology 114: 3-15.

Gall C., Balesdent M.H., Desthieux I., Robin P., Rouxel T. 1995. Polymorphism of Tox ${ }^{0}$ Leptosphaeria maculans isolates as revealed by soluble protein and isozyme electrophoresis. Mycological Research 99: 221-229.

Gladders P., Symonds B.V., Hardwick N.V., Sansford C.E. 1998. Opportunities to control canker (Leptosphaeria maculans) in winter oilseed rape by improved spray timing. International Organization for Biological Control Bulletin 21: 111-120. 
Gwiazdowski R. 2008. Hamowanie wzrostu Leptosphaeria maculans i Leptosphaeria biglobosa przez wybrane fungicydy w testach płytkowych. [Inhibition of growth of Leptosphaeria maculans and Leptosphaeria biglobosa in plating tests by some fungicides]. Rośliny Oleiste/Oilseed Crops 29: 67-73.

Jędryczka M. 2006. Epidemiologia i szkodliwość suchej zgnilizny kapustnych na rzepaku ozimym w Polsce. Rozprawy i Monografie IGR PAN 17, 150 ss.

Jędryczka M., Kaczmarek J. 2011. Ocena skuteczności wybranych fungicydów w zwalczaniu suchej zgnilizny kapustnych na rzepaku w terminie optymalnym i opóźnionym. [Efficiency of selected fungicides in protection against stem canker of brassicas in optimal and late spray time]. Progress in Plant Protection/Postępy w Ochronie Roślin 51 (4): 1639-1643.

Kaczmarek J., Brachaczek J., Jedryczka M. 2014. The effect of fungicide spray time on the incidence of stem canker of brassicas and seed yield of winter oilseed rape in Pomerania. Journal of Plant Diseases and Protection 121 (2): 58-63.

Kaczmarek J., Jędryczka M. 2010. Wpływ flusilazolu na wzrost grzybów chorobotwórczych Leptosphaeria maculans i L. biglobosa $\mathrm{w}$ warunkach in vitro. [The effect of flusilazole on in vitro growth of fungal pathogens Leptosphaeria maculans and L. biglobosa]. Progress in Plant Protection/Postępy w Ochronie Roślin 50 (2): 648-651.

Karolewski Z. 1998. The influence of fungicides on Phoma lingam (Tode ex. Fr.) Desm. mycelium growth. International Organisation for Biological Control Bulletin 21: 33-39.

Mendes-Pereira E., Balesdent M.-H., Brun H., Rouxel T. 2003. Molecular phylogeny of the Leptosphaeria maculans-L. biglobosa species complex. Mycological Research 107 (11): 1287-1304.

Payne R.W., Harding S.A., Murray D.A., Soutar D.M., Baird D.B., Welham S.J., Kane A.F., Gimour A.R., Thompson R., Webster R., Tunnicliffe-Wilson G. 2007. The Guide to GenStat Release 10, Part 2: Statistics. Oxford: VSN International, 423 pp.

Sewell T., Huang Y., Stotz H., Ashworth M., Walker P., Ritchie F., Fitt B.D.L. 2014. Effects of different fungicides on the severity of phoma stem canker. BSPP Presidential Meeting 2014, St. Andrews University, September 1-2, 2014, 112 pp.

Shoemaker R.A., Brun H. 2001. The teleomorph of the weakly aggressive segregate of Leptosphaeria maculans. Canadian Journal of Botany 79 (4): 412-419.

West J.S., Kharbanda P., Barbetti M.J., Fitt B.D.L. 2001. Epidemiology and management of Leptosphaeria maculans (phoma stem canker) in Australia, Canada and Europe. Plant Pathology 50 (1): 10-27. 